\title{
Kinerja Operasional Moda Bus Trans Mebidang Trayek Lubuk Pakam-Pusat Pasar Medan di Masa Pandemi Covid-19
}

\author{
Oloan SITOHANG ${ }^{1 *}$, Reynaldo SIAHAAN ${ }^{1}$, Arnoldus Yansen Berkat LAIA ${ }^{1}$ \\ ${ }^{1}$ Program Studi Teknik Sipil, Universitas Katolik Santo Thomas, email: obed_sito@yahoo.com
}

Sejarah artikel

Diserahkan: $\quad 18$ Agustus 2021

Dalam bentuk revisi: 26 September 2021

\author{
Diterima: $\quad 28$ September 2021 \\ Tersedia online: $\quad 30$ September 2021
}

\begin{abstract}
The COVID-19 pandemic has changed human behavior which resulted in a decrease in the movement of people and goods for certain purposes in Medan city. This study aims to identify the operational performance of the Trans Mebidang bus, in particular the Lubuk Pakam-Pusat Pasar route, and to analyze the current bus fare based on its operating income and costs (BOK) during this pandemic. This research method uses the technical guidelines of the Director General of Land Transportation (2002) as the source of indicators of operational performance and calculation of bus fare. There is a drop in performance, but relatively considered reasonable. Some of the performance indicators of Trans Mebidang on this route meet the standards, namely speed, travel time, passenger waiting time intervals. On the other hand, those that do not meet are the average load factor, headway, service time, and vehicle service frequency. The operational performance of this route can be stated as "medium", with an average score of 1.9 (out of 3). Fare adjustments can still be made to relieve the public, but this needs to be considered when the pandemic and restrictions get worse.
\end{abstract}

Keywords: operational performance, VOC, load factor, fare, covid19

\begin{abstract}
Abstrak
Pandemi covid-19 mengubah perilaku manusia yang berakibat menurunnya pergerakan manusia dan barang dari satu tempat ke tempat lain untuk tujuan tertentu di Kota Medan. Penelitian ini bertujuan untuk mengidentifikasi kinerja operasional moda bus trans Mebidang trayek Lubuk Pakam-Pusat Pasar Medan serta menganalisis tarif berdasarkan pendapatan dan biaya operasional kendaraan (BOK) selama pandemi. Metode penelitian ini menggunakan pedoman teknis Dirjen Perhubungan Darat tahun 2002 sebagai indikator kinerja operasional serta perhitungan tarif. Terdapat penurunan kinerja, tetapi cenderung dapat dianggap wajar. Beberapa kinerja operasional Trans Mebidang pada rute ini yang memenuhi standar adalah kecepatan, waktu tempuh, interval waktu tunggu penumpang. Sementara itu, yang tidak memenuhi adalah load factor rata-rata, headway, waktu pelayanan, frekuensi layanan kendaraan. Kinerja operasional Trans Mebidang rute ini dapat dinyatakan "sedang", dengan nilai rata-rata 1,9 (dari 3). Penyesuaian tarif masih dapat dilakukan untuk meringankan masyarakat, tetapi hal ini perlu mempertimbangkan ketika pandemi dan pembatasan semakin parah.
\end{abstract}

Kata kunci: kinerja operasional, BOK, load factor, tarif, covid19

\section{Pendahuluan}

Setelah wabah covid-19 dinyatakan sebagai bencana nasional oleh Presiden (Keppres No.12, 2020), pemerintah Indonesia menetapkan sejumlah langkah preventif dalam meredam tingkat penyebaran virus tersebut. Salah satunya adalah melalui pembatasan sosial dan kegiatan 
masyarakat, ditambah lagi dengan pembatasan layanan angkutan umum. Pembatasan sosial yang signfikan contohnya adalah: kerja dari rumah (work from home), pembelajaran daring, dan penutupan tempat perbelanjaan. Secara langsung, pembatasan ini berdampak pada menurunnya mobilitas masyarakat. Di Sumatera Utara, setelah pemberlakuan kebijakan tersebut, menurut Google COVID-19 Community Mobility Reports (2020) terjadi rata-rata sekitar 35\% penurunan mobilitas masyarakat selama bulan April-Mei tahun 2020. Penurunan signifikan terjadi pada perjalanan ke tempat rekreasi seperti taman $(36,9 \%)$, ke pusat perbelanjaan $(36,8 \%)$, ke simpul transportasi $(49,9 \%)$, dan tempat kerja $(30,3 \%)$.

Tidak hanya kuantitas, perilaku perjalanan masyarakat di Indonesia juga berubah akibat adanya pandemi covid-19. Paradigma terkait tingkat keseriusan dan bahaya virus ini menjadi salah satu yang signifikan mempengaruhi (Irawan, dkk., 2021). Di Kota Medan secara khusus, belum terdapat referensi yang dapat diangkat terkait hal ini. Meskipun demikian, kota lain di negara tetangga mengalami kondisi yang sama, secara spesifik adanya kecenderungan memilih kendaraan pribadi daripada angkutan umum (Phandanouvong, dkk., 2021). Dalam hal ini, moda transportasi publik terutama di perkotaan berada pada posisi yang sulit. Transportasi publik memiliki citra berbahaya di masyarakat karena beresiko menjadi tempat penularan covid-19 terutama jika tidak disipilin menerapkan social distancing (Tirachini \& Cats, 2020).

Kota Medan sebagai kota besar di provinsi Sumatera Utara memiliki sentra aktivitas dan kebutuhan yang cukup banyak. Hal ini menarik perjalanan dari masyarakat yang berada di sekitar Kota Medan, terutama untuk tujuan pekerjaan dan kegiatan perniagaan. Dua contoh rute perjalanan harian yang rutin adalah berasal dari Kota Binjai dan Kota Lubuk Pakam yang berbatasan langsung dengan Kota Medan. Selain dengan kendaraan pribadi dan angkutan kota (angkot), rute ini biasanya dilayani oleh masing-masing koridor Bus Rapid Transit (BRT) Trans Mebidang. Koridor BRT ini telah beroperasi sejak tahun 2015. Rutinitas di atas, yang terdisrupsi kebijakan pembatasan sosial, cenderung akan mempengaruhi kinerja operasional Trans Mebidang.

Literatur yang mengkaji kinerja operasional transportasi publik, khususnya di Kota Medan, masih sangat sulit ditemukan karena jumlahnya yang sangat minimal. Beberapa studi terpublikasi telah dilakukan di luar Kota Medan, seperti yang dibahas (Sultan, dkk., 2020) terkait angkutan perairan, (Stini, 2020) terkait angkutan massal Transjakarta, serta beberapa penelitian terhadap kinerja operasional bus yang belum dipublikasikan seperti yang dilakukan (Harahap, 2020) dan (Wijaya, 2021). Dalam hal ini, bagaimana kinerja operasional Trans Mebidang saat pandemi dengan adanya pemberlakuan berbagai kebijakan pembatasan sosial adalah topik yang perlu untuk diteliti. Kinerja operasional dapat dibahas dengan meninjau pedoman teknis penyelenggaraan angkutan umum dan analisis biaya operasional kendaraan yang dirilis oleh Dirjen Perhubungan Darat. Studi ini dapat memberikan gambaran kondisi yang dialami oleh Trans Mebidang di masa pandemi covid-19, dan selanjutnya menjadi wawasan mendukung kebijakan akan transportasi publik pada kondisi bencana serupa di masa depan.

\section{Metodologi}

Penelitian ini dilaksanakan dengan tahapan sebagai berikut: survei pendahuluan, survei primer melalui observasi lapangan disertai kuesioner wawancara, kompilasi dan analisis data, serta diakhiri dengan pembahasan dan penarikan kesimpulan.

\section{Survei Pendahuluan}

Survei pendahuluan dilakukan pada tanggal 12 Pebruari 2020 di trayek Terminal Lubuk Pakam-Pusat Pasar Kota Medan. Tujuan survei adalah untuk mengetahui karakteristik dasar layanan objek penelitian seperti: jarak tempuh lintasan, waktu perjalanan pelayanan, posisi halte, kapasitas tempat duduk, dan rute pulang-pergi. Survei ini juga dilakukan untuk merencanakan jumlah surveyor, model kusioner dan wawancara, waktu pelaksanaan survei, alat yang digunakan, serta jumlah sampel minimal yang dibutuhkan. 


\section{Data Penelitian dan Sumber Data}

Objek penelitian ini adalah armada BRT Trans Mebidang dengan rute Lubuk Pakan-Pusat Pasar. Data sekunder diperoleh dari instansi terkait (biaya operasi kendaraan, hari operasi/bulan, tarif berlaku, pendapatan kotor dan jumlah bus beroperasi). Sementara, data primer mengacu pada SK.687/AJ.206/DRJD/2002 tentang Pedoman Teknis Penyelenggraan Angkutan Penumpang Umum Di Wilayah Perkotaan Dalam Trayek Tetap Dan Teratur (2002). Data primer yang dikumpulkan, antara lain jumlah naik turun penumpang, waktu perjalanan, frekuensi pelayanan, waktu antara, jumlah penumpang, jarak tempuh dan pendapatan. Terakhir, data karakteristik penumpang diperoleh dari penyebaran kuesioner kepada penumpang.

\section{Teknik Pengumpulan Data}

Data primer dan kuesioner diperoleh melalui pengamatan dalam Bus (on board survey) menggunakan lembar kerja bemuatan: data faktor muat, kecepatan perjalanan, waktu antara, waktu tempuh/ perjalanan, waktu tunggu, waktu pelayanan, dan frekuensi kendaraan (kend/jam). Wawancara dengan kuesioner juga dilakukan di di dalam bus, tetapi dengan surveyor berbeda. Oleh karena populasi tidak diketahui, jumlah sampel minimum yang dibutuhkan diestimasi dengan rumus Lemeshow (Levy \& Lemeshow, 2013) di bawah ini.

$$
n=\frac{Z^{2} * P(1-P)}{d^{2}}
$$

dimana $Z 1,96, p=$ maksimal estimasi $(0,5)$, dan $d=$ alpha (0.05). Hasil perhitungan jumlah minimum (dengan galat 10\%) adalah 96 responden. Dalam penelitian ini diperoleh jumlah sampel 200 orang.

\section{Analisis Data Kinerja Operasional Bus}

\section{$\underline{\text { Load Factor }(L F)}$}

$$
\begin{aligned}
& L F L=\frac{A F k}{K L t} * 100 \% \\
& A F k=\sum_{i}^{n=1}(i, i+1) * \text { Pobi } \\
& K L t=L_{L} * K T_{r}
\end{aligned}
$$

dimana: LFL adalah Load Factor (\%), Afk adalah Luas faktual loading profile dari titik pemberhentian i ke $\mathrm{n}$ (pnp.km), KLt adalah Luas loading profile (panjang lintasan $\times$ kapasitas lintas) pnp.km, Pobi adalah penumpang on board pada titik pemberhentian i (pnp), Titik i adalah Mulai dari $1, \ldots \mathrm{n}, \mathrm{Li}, \mathrm{i}+1=$ Panjang ruas $\mathrm{km}, \mathrm{L} \_\mathrm{L}=$ Panjang Lintas dari terminal awal ke terminal akhir (LAB) dan KTr adalah kapasitas teoritis kendaraan (45 pnp).

\section{$\underline{\text { Kecepatan Perjalanan }}$}

$$
v=\frac{60 j}{T}
$$

dimana, $\mathrm{v}$ adalah kecepatan perjalanan $(\mathrm{km} / \mathrm{jam})$, $\mathrm{j}$ adalah jarak rute $(\mathrm{km})$, dan $\mathrm{T}$ adalah waktu tempuh (menit).

\section{Headway (H), Waktu Perjalanan, Waktu Tunggu, dan Waktu Pelayanan)}

Headway dihitung sebagai selisih antara waktu kedatangan angkutan pertama pada titik tinjauan $\left(\mathrm{T}_{1}\right)$, dan waktu kedatangan angkutan kedua pada titik tinjauan $\left(\mathrm{T}_{2}\right)$. Sedangkan, waktu perjalanan dihitung dengan menggunakan Persamaan 6 berikut ini. 


$$
W=\frac{T}{J}
$$

dimana $\mathrm{W}$ adalah waktu perjalanan (menit), $\mathrm{J}$ adalah jarak antara segmen $(\mathrm{km})$, dan $\mathrm{T}$ adalah waktu tempuh (menit). Sedangkan, waktu tunggu dan waktu pelayanan (jam operasi) didata secara manual di lapangan.

\section{Frekuensi Pelayanan}

$$
f=\frac{1}{H}
$$

dimana: f adalah frekuensi (kendaraan/jam), dan $\mathrm{H}$ adalah headway (jam/kendaraan).

\section{$\underline{\text { Tarif }}$}

Secara matematis tarif dihitung dengan persamaan berikut:

$$
\begin{aligned}
& \text { Tarif }=(\text { tarif pokok } * \text { jarak rata }- \text { rata })+10 \% * \text { tarif BEP } \\
& \text { Tarif BEP }=\text { tarif pokok } * \text { jarak rata }- \text { rata } \\
& \text { Tarif pokok }=\frac{\text { total biaya pokok }}{\text { faktor pengisian } * \text { kapasitas kendaraan }} \\
& \text { Faktor pengisian }(\mathrm{F})=\mathrm{PK} * 100 \%
\end{aligned}
$$

dimana: $\mathrm{F}$ adalah faktor muat, $\mathrm{P}$ adalah banyaknya penumpang, dan $\mathrm{K}$ adalah daya tampung kendaraan.

\section{Analisis Biaya Operasional Kendaraan (BOK)}

BOK adalah hasil penjumlahan biaya langsung dan biaya tak langsung. Biaya langsung terdiri dari biaya tetap (biaya penyusutan, biaya bunga modal, biaya pajak, biaya kir, biaya asuransi, biaya retribusi terminal) dan biaya tidak tetap (biaya awak bus, biaya BBM, biaya ban, biaya pemeliharaan/reprasi kendaraan). Sementara itu, biaya tidak langsung terdiri dari: biaya gaji pegawai dan biaya pengelolaan. Terakhir, biaya overhead adalah $20-25 \%$ dari total biaya langsung dan tidak langsung di atas. Perhitungan BOK dilanjutkan dengan perhitungan pendapatan yang mana merupakan selisih antara pendapatan kotor pertahun dengan BOK pertahun. Nilai pendapatan dan BOK kemudian digunakan untuk menentukan Fare Box Ratio, yang merupakan perbandingan antara pendapatan dan biaya operasional kendaraan.

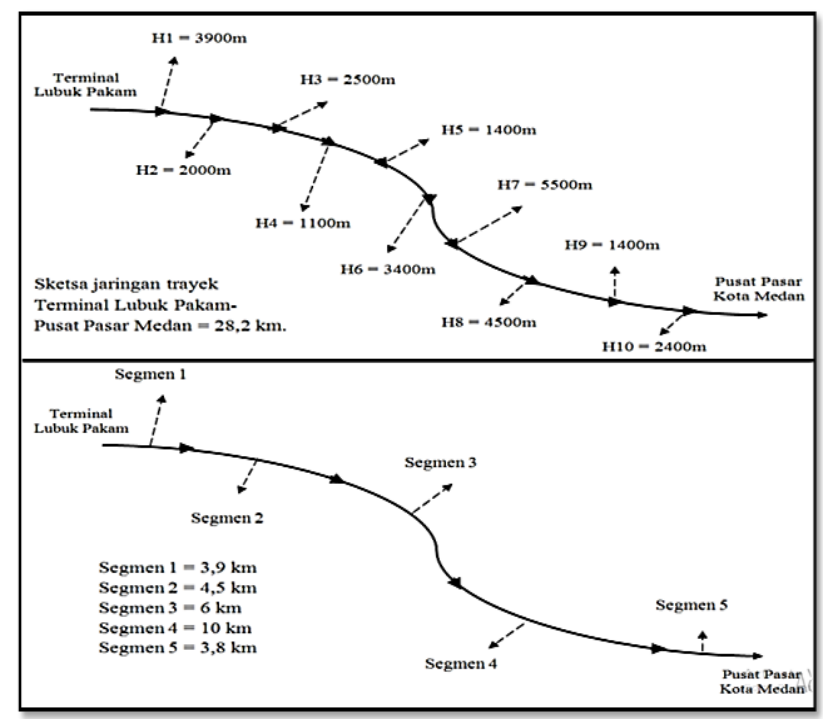

Gambar 1. Sketsa trayek dan panjang segmen terminal lubuk pakam 


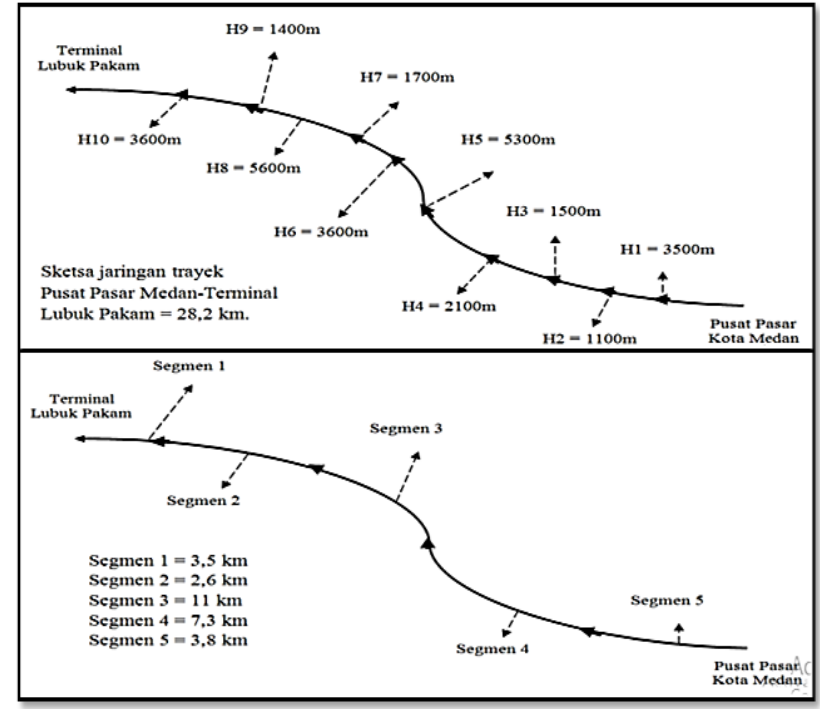

Gambar 2. Sketsa trayek dan panjang segmen pusat pasar medan

\section{Hasil}

\section{Penentuan Segmen}

Hasil survei pendahuluan memberikan gambaran secara umum trayek Terminal Lubuk Pakam - Pusat Pasar Medan pulang pergi seperti disajikan pada Gambar 1 dan Gambar 2.

\section{Karakteristik Penumpang/Responden}

Karakteristik sosio-ekonomi dan perjalanan responden sebanyak 200 orang ditinjau dari jenis kelamin, usia, pendidikan, pekerjaan, pendapatan, tujuan perjalanan, frekuensi perjalanan dapat dilihat pada Tabel 2. Tabel tersebut menunjukkan bahwa responden dominan pria (58\%), tingkat Pendidikan SMA (42\%), umur 21-30 tahun (32\%), pekerjaan di luar PNS, wiraswasta, karyawan swasta, dan mahasiswa (34\%), pendapatan bulanan kurang dari 1 juta (40\%). Dalam kuesioner yang dibagikan kepada penumpang, terdapat pula beberapa pertanyaan persepsional dan opini (tanggapan tarif yang berlaku, alasan menggunakan armada dan saran responden) terhadap layanan BRT Trans Mebidang saat ini. Hasil survei tanggapan disajikan pada Tabel 1 di bawah ini.

Tabel 1. Persepsi dan opini penumpang terhadap layanan

\begin{tabular}{|c|c|c|}
\hline \multicolumn{2}{|r|}{ Persepsi dan Opini } & $\%(\mathrm{~N}=\mathbf{2 0 0})$ \\
\hline \multirow{2}{*}{$\begin{array}{l}\text { Tanggapan Tarif } \\
\text { Berlaku }\end{array}$} & Setuju & 45 \\
\hline & Tidak & 55 \\
\hline \multirow[t]{7}{*}{ Saran Responden } & Jumlah armadanya ditambah & 9 \\
\hline & Jalurnya diperpanjang Melintasi Kota Medan dan Kota Lubuk Pakam & 15 \\
\hline & $\begin{array}{l}\text { Perlunya aplikasi pintar mengetahui informasi kedatangan dan } \\
\text { keberangkatan bus }\end{array}$ & 14 \\
\hline & Angkutannya diperbaiki, lebih bersih, bangkunya dibenahi & 23 \\
\hline & Dibuat berjadwal dan informasi lewatnya bus disetiap halte & 11 \\
\hline & Perlunya halte dibenahi dan diberi tempat duduk untuk menunggu bus & 13 \\
\hline & Pemasangan Kamera CCTV untuk Keamanan & 15 \\
\hline \multirow{5}{*}{$\begin{array}{l}\text { Alasan } \\
\text { Menggunakan } \\
\text { Armada }\end{array}$} & Perjalanan panjang & 25 \\
\hline & Ongkos lebih murah & 21 \\
\hline & Fasilitas lebih nyaman & 21 \\
\hline & Terjangkau dari tempat tinggal/tujuan akhir & 15 \\
\hline & Terhindar dari Kejahatan dan Kecelakaan & 18 \\
\hline
\end{tabular}


JURNAL REKAYASA KONSTRUKSI MEKANIKA SIPIL (JRKMS)

Volume 04 Nomor 02 September 2021

p-ISSN 2614-5707 e-ISSN 2715-1581

Tabel 2. Karakteristik penumpang

\begin{tabular}{|c|c|c|}
\hline \multicolumn{2}{|c|}{ Karakteristik } & $\%(\mathrm{~N}=200)$ \\
\hline \multirow[t]{2}{*}{ Gender } & Pria & 42 \\
\hline & Wanita & 58 \\
\hline \multirow[t]{5}{*}{ Kelompok Usia } & 12-20 tahun & 21 \\
\hline & $21-30$ tahun & 32 \\
\hline & $31-40$ tahun & 18 \\
\hline & 41-50 tahun & 21 \\
\hline & $51-60$ tahun & 8 \\
\hline \multirow[t]{4}{*}{ Pendidikan Terakhir } & SD & 3 \\
\hline & SMP & 28 \\
\hline & SMA & 42 \\
\hline & S1 & 28 \\
\hline \multirow[t]{5}{*}{ Pekerjaan } & PNS & 5 \\
\hline & Wiraswasta & 18 \\
\hline & Karyawan Swasta & 26 \\
\hline & Mahasiswa & 18 \\
\hline & Lainnya & 34 \\
\hline \multirow[t]{6}{*}{ Pendapatan Bulanan } & kurang dari 1 juta & 40 \\
\hline & $1-2$ juta & 16 \\
\hline & $2-3$ juta & 23 \\
\hline & 3-5 juta & 19 \\
\hline & 5-10 juta & 2 \\
\hline & lebih dari 10 juta & 0 \\
\hline \multirow[t]{5}{*}{ Frekuensi Menggunakan Bus } & Setiap Hari & 27 \\
\hline & 1/Seminggu & 17 \\
\hline & 2-3/Seminggu & 17 \\
\hline & 4-5/Seminggu & 13 \\
\hline & Sangat Jarang, Tidak Tentu & 26 \\
\hline \multirow[t]{5}{*}{ Tujuan Perjalanan } & Pendidikan & 19 \\
\hline & Belanja & 22,5 \\
\hline & Bekerja & 25,5 \\
\hline & Rekreasi/jalan-jalan & 30,5 \\
\hline & Lainnya & 2,5 \\
\hline
\end{tabular}

\section{Kinerja Operasional Bus Damri}

Kinerja Moda Trans Mebidang rute Lubuk Pakam-Pusat Pasar berupa load factor, kecepatan perjalanan, waktu tempuh, waktu antara (headway), waktu tunggu penumpang, waktu pelayanan dan tarif yang diberlakukan. Tabel 3 di bawah menunjukkan hasil olahan data load factor, kecepatan perjalanan dan waktu tempuh yang terjadi di lapangan. Load factor minimum $25,25 \%$, load factor maximum $83,69 \%$ load factor rata-rata 53,84\%. Kecepatan perjalanan minimum $21,8 \mathrm{~km} / \mathrm{jam}$, kecepatan perjalanan maximum $36,5 \mathrm{~km} / \mathrm{jam}$ dan kecepatan perjalanan rata-rata $29,3 \mathrm{~km} / \mathrm{jam}$. Waktu tempuh minimum 1,67 menit-perkm, waktu tempuh maximum 2,76 menit-perkm dan waktu tempuh rata-rata 2,11 menit-perkm.

Tabel 3. Nilai load factor, kecepatan dan waktu tempuh Lubuk Pakam-Pusat Pasar pulang pergi

\begin{tabular}{|l|c|c|c|c|c|c|c|c|c|}
\hline \multirow{2}{*}{ Hari } & \multicolumn{3}{|c|}{ Load factor $(\%)$} & \multicolumn{3}{c|}{ Kecepatan Perjalanan (km/jam) } & \multicolumn{3}{c|}{ Waktu Tempuh (menit/km) } \\
\cline { 2 - 9 } & min & max & rerata & min & max & rerata & min & max & rerata \\
\hline $\begin{array}{l}\text { Minggu, } \\
\text { 3-5-2020 }\end{array}$ & 20,57 & 73,45 & 47,83 & 22,28 & 34,76 & 28,99 & 1,74 & 2,70 & 2,11 \\
\hline $\begin{array}{l}\text { Senin, } \\
\text { 4-5-2020 }\end{array}$ & 29,62 & 99,01 & 64,44 & 20,9 & 34,3 & 28,84 & 1,76 & 2,89 & 2,15 \\
\hline $\begin{array}{l}\text { Sabtu, } \\
\text { 9-5-2020 }\end{array}$ & 25,55 & 78,60 & 49,25 & 22,3 & 40,5 & 30,06 & 1,51 & 2,70 & 2,08 \\
\hline rerata & 25,25 & 83,69 & 53,84 & 21,8 & 36,5 & 29,3 & 1,67 & 2,76 & 2,11 \\
\hline
\end{tabular}

Faktor lainnya adalah waktu antara (headway) dan frekuensi pelayanan dapat dilihat pada Tabel 4. Dari pengamatan diperoleh nilai headway rata-rata 29,71 menit hari Minggu, 22,00 menit hari Senin dan 21,35 hari Sabtu. Frekuensi pelayanan rata-rata 2,02 kend/jam hari Minggu, 2,73 kend/jam hari Senin dan 2,81 kend/jam hari Sabtu. Bila nilai headway menurun maka akan menghasilkan nilai frekuensi meningkat. 
JURNAL REKAYASA KONSTRUKSI MEKANIKA SIPIL (JRKMS)

Volume 04 Nomor 02 September 2021

p-ISSN 2614-5707 e-ISSN 2715-1581

Tabel 4. Nilai headway dan frekuensi pelayanan Lubuk Pakam-Pusat Pasar pulang pergi

\begin{tabular}{|l|c|c|c|c|c|c|}
\hline \multirow{2}{*}{\multicolumn{1}{c|}{ Hari }} & \multicolumn{3}{|c|}{ Headway (menit) } & \multicolumn{3}{c|}{ Frekuensi kend/jam (60/H) } \\
\cline { 2 - 7 } & Min & Max & Rata-rata & Min & Max & Rata-rata \\
\hline Minggu, 3-5-2020 & 18,00 & 36,50 & 29,71 & 3,33 & 1,64 & 2,02 \\
\hline Senin, 4-5-2020 & 12,50 & 32,00 & 22,00 & 4,80 & 1,88 & 2,73 \\
\hline Sabtu, 9-5-2020 & 12,00 & 31,50 & 21,35 & 5,00 & 1,90 & 2,81 \\
\hline Rata-rata & 14,17 & 33,33 & 24,35 & 4,38 & 1,81 & 2,52 \\
\hline
\end{tabular}

Sementara itu, durasi terpanjang faktor waktu tunggu penumpang diperoleh 10-15 menit $(38 \%)$. Menurut indikator standar kinerja operasional kendaraan, durasi terlama untuk waktu tunggu ini tergolong baik karena berada di bawah 20 menit.

\section{Biaya Operasi Kendaraan (BOK)}

Perhitungan BOK diperoleh dengan memperhatikan KM 89 Tahun 2002 Tentang Mekanisme Penetapan Tarif Dan Formula Perhitungan Biaya Pokok Angkutan Penumpang Dgn Mobil Bus Umum Antar Kota Kelas Ekonomi (2002). Rekapitulasi hasilnya disajikan pada Tabel 5 di bawah ini.

Tabel 5. Rekapitulasi biaya pokok per penumpang

\begin{tabular}{|c|c|c|c|c|c|c|}
\hline No & Komponen Biaya & $\begin{array}{r}\text { Rp/Bus } \\
\text { (km) }\end{array}$ & $\begin{array}{r}\text { Rp/Bus } \\
\text { (km) }\end{array}$ & $\begin{array}{r}\text { Rp/Bus } \\
\text { (rit) }\end{array}$ & $\begin{array}{r}\text { Margin } \\
(\mathbf{1 0 \%})\end{array}$ & $\begin{array}{r}\text { Tarif } \\
/ \text { pnp/rit }\end{array}$ \\
\hline 1 & Biaya Langsung & 4.676 & 193 & 5.443 & 544 & 5.987 \\
\hline \multirow[t]{7}{*}{$\mathrm{A}$} & Biaya tetap & 1.570 & 64 & 1.828 & 183 & 2.010 \\
\hline & Biaya penyusutan & 1.241 & 51 & 1.444 & 144 & 1.589 \\
\hline & Biaya bunga modal & - & - & - & - & - \\
\hline & Biaya STNK & 28 & 1 & 33 & 3 & 36 \\
\hline & Biaya KIR & 4 & 0 & 5 & 0 & 5 \\
\hline & Asuransi kendaraan & 194 & 8 & 226 & 23 & 248 \\
\hline & Retribusi parkir kendaraan & 103 & 4 & 120 & 12 & 132 \\
\hline \multirow[t]{5}{*}{$\mathrm{B}$} & Biaya Tidak Tetap & 3.106 & 129 & 3.615 & 361 & 3.976 \\
\hline & Biaya awak bus & 646 & 27 & 752 & 75 & 827 \\
\hline & Biaya BBM & 1.300 & 54 & 1.513 & 151 & 1664 \\
\hline & Biaya ban & 310 & 13 & 361 & 36 & 397 \\
\hline & Biaya pemeliharaan kendaraan & 850 & 35 & 989 & 99 & 1.088 \\
\hline \multirow[t]{3}{*}{2} & Biaya Tidak Langsung & 1.236 & 51 & 1.439 & 282 & 3.097 \\
\hline & Biaya gaji pegawai & 659 & 27 & 767 & 77 & 844 \\
\hline & Biaya Pengelolaan & 577 & 24 & 672 & 67 & 739 \\
\hline \multirow[t]{2}{*}{3} & Biaya Overhead & 1.182 & 49 & 1.376 & 138 & 1.514 \\
\hline & Jumlah & 7.094 & 293 & 8.257 & 826 & 9.083 \\
\hline
\end{tabular}

\section{Simulasi Kinerja Angkutan Damri dan Tarif}

Perhitungan tarif dengan simulasi hubungan tarif dengan variasi load factor antara $10 \%$ hingga $100 \%$ dapat dilihat pada Tabel 6. Pada masa pandemi covid-19 ini menunjukkan load factor $=10 \%$ menginginkan tarif Rp. 48.900, load factor minimum $25,25 \%$ menginginkan tarif Rp. 19.366, load factor rata-rata $=53,84 \%$ menginginkan tarif Rp. 9.118, load factor $=$ $70 \%$ menginginkan tarif Rp. 6.986, load factor maksimum $=83,69 \%$ menginginkan tarif $=$ Rp. 5.843 dan load factor $100 \%$ menginginkan tarif $=$ Rp. 4.890. Berdasarkan nilai load factor yang divariasikan tersebut dapat dinyatakan bahwa tarif yang berlaku dapat ditinjau ulang oleh pemerintah untuk membantu masyarakat yang berpenghasilan rendah dengan batas selisih penerimaan dan pengeluaran adalah impas. 
JURNAL REKAYASA KONSTRUKSI MEKANIKA SIPIL (JRKMS)

Volume 04 Nomor 02 September 2021

p-ISSN 2614-5707 e-ISSN 2715-1581

Tabel 6. Hubungan simulasi kinerja dan tarif

\begin{tabular}{|c|c|c|c|c|c|c|c|}
\hline $\begin{array}{c}\text { Load factor } \\
(\%)\end{array}$ & $\begin{array}{c}\text { Tarif } \\
\text { pokok }\end{array}$ & $\begin{array}{c}\text { Kapasitas } \\
\text { bus }\end{array}$ & $\begin{array}{c}\text { Jarak } \\
\text { km }\end{array}$ & $\begin{array}{l}\text { Tarif Pokok } \\
\text { pnp-km (Rp) }\end{array}$ & $\begin{array}{l}\text { Tarif BEP } \\
\text { (Rp) }\end{array}$ & $\begin{array}{l}\text { Margin } \\
\text { (Rp) }\end{array}$ & Tarif (Rp) \\
\hline [1] & {$[2]$} & [3] & [4] & {$[5]=(2 / 1) * 3$} & {$[6]=(4 * 5)$} & {$[7]=(6 * 10 \%)$} & {$[8]=(6+7)$} \\
\hline 10 & \multirow[t]{13}{*}{7.094} & \multirow[t]{13}{*}{45} & \multirow[t]{13}{*}{28,2} & $1.576,40$ & $44.454,47$ & $4.445,45$ & 48.900 \\
\hline 20 & & & & 788,20 & $22.227,24$ & $2.222,72$ & 24.450 \\
\hline 25,25 & & & & 624,31 & $17.605,73$ & $1.760,57$ & 19.366 \\
\hline 30 & & & & 525,47 & $14.818,16$ & $1.481,82$ & 16.300 \\
\hline 40 & & & & 394,10 & $11.113,62$ & $1.111,36$ & 12.225 \\
\hline 50 & & & & 315,28 & $8.890,89$ & 889,09 & 9.780 \\
\hline 53,84 & & & & 293,94 & $8.289,11$ & 828,91 & 9.118 \\
\hline 60 & & & & 262,73 & $7.409,08$ & 740,91 & 8.150 \\
\hline 70 & & & & 225,20 & $6.350,64$ & 635,06 & 6.986 \\
\hline 80 & & & & 197,05 & $5.556,81$ & 555,68 & 6.112 \\
\hline 83,69 & & & & 188,36 & $5.311,80$ & 531,18 & 5.843 \\
\hline 90 & & & & 175,16 & $4.939,39$ & 493,94 & 5.433 \\
\hline 100 & & & & 157,64 & $4.445,45$ & 444,54 & 4.890 \\
\hline
\end{tabular}

\section{Pendapatan}

Pendapatan adalah jumlah penerimaan kotor rata-rata perhari dari ongkos yang dibayarkan penumpang dan penerimaan bersih adalah pendapatan kotor operator dikurangi biaya-biaya yang terjadi dalam keperluan pengoperasian.Untuk menentukkan jumlah pendapatan/tahun/kendaraan yaitu perkalian hari operasi dalam setahun dengan jumlah penumpang dalam satu hari dengan tarif yang berlaku per orang. Asumsi hari operasi dalam setahun adalah 365 hari waktu normal dan 320 hari waktu efektif. Perhitungan pendapatan dengan tarif berlaku sebesar Rp. 7.000 untuk seluruh kalangan dapat dilihat pada Tabel 7 di bawah ini.

Tabel 7. Jumlah biaya operasional kendaraan per tahun

\begin{tabular}{|l|c|c|c|}
\hline \multicolumn{1}{|c|}{ Jenis Biaya } & $\begin{array}{c}\text { Harga } \\
\text { (Rp) }\end{array}$ & $\begin{array}{c}\text { Km Tempuh/ } \\
\text { Tahun/Bus (km) }\end{array}$ & $\begin{array}{c}\text { Biaya Operasinal } \\
\text { kendaraan/Tahun (Rp) }\end{array}$ \\
\hline Biaya Langsung & 4.676 & 78.076 & 365.088 .137 \\
\hline Biaya Tidak Langsung & 1.235 & 78.076 & 96.455 .966 \\
\hline Biaya Over Head & 1.182 & 78.076 & 92.308 .821 \\
\hline \multicolumn{3}{|r|}{ Total } & $\mathbf{5 5 3 . 8 5 2 . 9 2 3}$ \\
\hline
\end{tabular}

Berdasarkan hasil Biaya Operasi Kendaraan per tahun pada Tabel 7 di atas dapat diketahui biaya operasi satu kendaraan dengan jarak tempuh $78.076 \mathrm{~km}$ sebesar Rp.553.852.923 per tahun.

\section{Asumsi Jumlah Penumpang dalam 1 Tahun}

Jumlah penumpang bus Damri berdasarkan data primer yang dikumpulkan selama 3 hari, yakni: Minggu, Senin mewakili hari kerja (Senin-Jumat) dan Sabtu diasumsikan mewakili hari dalam satu minggu dan dikonversi menjadi satu tahun. Sehingga jumlah penumpang satu minggu dapat dihitung seperti dilihat pada Tabel 8 di bawah ini

Tabel 8. Jumlah penumpang saat kondisi normal dan efektif dalam satu tahun

\begin{tabular}{|c|c|c|c|c|c|c|c|}
\hline \multirow{2}{*}{ Hari } & \multirow{2}{*}{$\begin{array}{c}\text { Jumlah } \\
\text { penumpang/hari }\end{array}$} & \multirow{2}{*}{$\begin{array}{l}\text { Jumlah } \\
\text { Hari }\end{array}$} & \multirow{2}{*}{$\begin{array}{c}\text { Jumlah } \\
\text { penumpang }\end{array}$} & \multicolumn{2}{|c|}{ Jumlah Hari } & \multicolumn{2}{|c|}{ Jumlah pnp/tahun } \\
\hline & & & & Normal & Efektif & Normal & Efektif \\
\hline Minggu & 178 & 1 & 178 & \multirow{3}{*}{365} & \multirow{3}{*}{320} & \multirow{3}{*}{83.614} & \multirow{3}{*}{73.305} \\
\hline Senin-Jumat & 248 & 5 & 1.242 & & & & \\
\hline Sabtu & 184 & 1 & 184 & & & & \\
\hline Total & & 7 & 1.604 & & & & \\
\hline Rata-rata & & & 229 & & & & \\
\hline
\end{tabular}




\section{Pembahasan}

\section{Kinerja Operasional Bus Damri}

Kajian pertama adalah bagaimana kinerja operasional bus Damri Trans Mebidang di masa pandemi covid-19 atas diberlakukannya pembatasan pergerakan manusia dalam hal bekerja, sekolah dan belanja dari rumah. Tabel 2 menunjukkan bahwa pengguna dominan sebagai profesi lainnya (di luar PNS, karyawan swasta, dan mahasiswa), rata-rata usia muda, dan memiliki pendapatan sangat rendah sekali. Di sisi lain pada saat jam puncak load factor aktual cenderung lebih besar dari load factor 70\%, meskipun hasil rata-rata di bawah load factor yang ditetapkan. Hal ini berarti bahwa masyarakat belumlah sepenuhnya memenuhi peraturan yang ditetapkan oleh pemerintah akibat keinginan pemenuhan kebutuhan kehidupannya. Dengan kata lain, masyarakat secara umum dapat dikatakan belum memahami sepenuhnya pengaruh pandemi covid-19 dalam kesehatannya, sehingga kemungkinan besar akan sulit untuk membatasi peningkatan masa pandemi covid-19 apalagi untuk menghilangkannya.

Pandemi covid-19 sangat mempengaruhi kinerja operasional Trans Mebidang seperti ditunjukkan pada Tabel 9 di bawah. Hasil penilaian kinerja operasional Trans Mebidang sesuai indikator kinerja operasional Standar Direktorat Jenderal Perhubungan Darat tahun 2002.

Tabel 9. Hasil perbandingan kinerja operasional berdasarkan pedoman Dirjen Hubdat (2002)

\begin{tabular}{|l|c|c|c|}
\hline \multicolumn{1}{|c|}{ Indikator Pelayanan } & Standar Kinerja Operasional & Hasil & \multicolumn{2}{c|}{ Ket } \\
\hline Load Factor $(\%)$ & $>70 \%$ & 53,63 & Tidak Memenuhi \\
\hline Kecepatan perjalanan (km/jam) & $>10$ & 29,25 & Memenuhi \\
\hline Headway ( menit ) & $<10$ & 23,95 & Tidak Memenuhi \\
\hline Waktu Perjalanan ( menit/km) & $<6$ & 2,1 & Memenuhi \\
\hline Waktu tunggu (menit) & $<20$ & $10-15$ & Memenuhi \\
\hline Waktu Pelayanan (jam) & $>12$ & 11,01 & Tidak Memenuhi \\
\hline Frekuensi (kend/jam) & $>6$ & 2,6 & Tidak Memenuhi \\
\hline
\end{tabular}

Pada Tabel 9 di atas menunjukkan dari 9 kinerja yang diukur ada 4 indikator "tidak memenuhi" kriteria yakni indikator load factor, headway, waktu pelayanan, dan frekuensi kendaraan. Indikator headway, waktu pelayanan, frekuensi pada masa pandemi covid-19 diperoleh tidak memenuhi kriteria yang ditetapkan. Hal ini berpeluang besar disebabkan oleh kecenderungan perilaku pengemudi yang sering memperlambat kendaraan sambil memperhatikan penumpang di sepanjang rute. Saat ini naik turunnya penumpang belum dilakukan di halte, melainkan bisa di sepanjang rute. Indikator load factor secara logika akan berada di bawah load factor desain $70 \%$ karena masyarakat dibatasi pergerakannya dan secara psikologis masih mengalami trauma akibat banyak pemberitaan dari media social memberikan informasi kematian akibat pandemi covid-19. Secara rata-rata, load factor $53,65 \%$ tidak memenuhi standar. Meskipun demikian, pada saat jam puncak pagi dan sore nilai load factor berada di atas kriteria ini $(>70 \%)$. Hal ini menunjukkan masih banyak masyarakat kurang peduli atas kebijakan pemerintah dengan work fom home (wfh), terlebih lagi karena alasan pemenuhan kebutuhannya.

Kondisi kurangnya pemahaman penumpang (Anggraeni, 2021) akan bahaya dan penyebaran covid-19 cenderung memperlambat pengendalian virus tersebut. Kebijakan pembatasan kapasitas penumpang sendiri ditetapkan satu bulan setelah survei ini melalui Surat Edaran Menteri Perhubungan No. 11 TAHUN 2020 tentang Pedoman Dan Petunjuk Teknis Penyelenggaraan Transportasi Darat Pada Masa Adaptasi Kebiasaan Baru Untuk Mencegah Penyebaran Corona Virus Disease 2019 (COVID-19, 2020). Dengan dirilisnya surat edaran ini, load factor pada jam puncak tentu akan berkurang dari data yang telah kami tampilkan. Implementasi kebijakan pembatasan kapasitas serta jarak minimal antarpenumpang adalah penting untuk dilaksanakan dengan disiplin. Hal ini disebabkan pembatasan sosial dan pergerakan justru tidak efektif apabila protokol kesehatan seperti physical distancing tidak dilakukan (Chinazzi, dkk., 2020; Tirachini \& Cats, 2020). 
Faktor kecepatan perjalanan, waktu perjalanan dan waktu tunggu penumpang adalah "memenuhi standar" yang ditetapkan. Walaupun kecepatan kendaraan cenderung berdasarkan keinginan pribadi supir, tetapi kecepatan dan waktu perjalanan masih memenuhi standar karena interaksi dengan kendaraan lain sangat rendah dengan adanya pembatasan pergerakan manusia tersebut. Durasi waktu tunggu juga memenuhi standar kriteria, karena kedua belah pihak saling membutuhkan.

Angka indikator tersebut perlu diukur dengan skala penilaian yang dikeluarkan oleh Diejen Hubdat 2002 tentang Skala Penilaian Kinerja Operasional kendaraan untuk menentukan kinerja operasional bus tersebut seperti tercantum pada Tabel 10 berikut ini.

Tabel 10. Skala penilaian kinerja operasional kendaraan berdasarkan Dirjen Hubdat 2002

\begin{tabular}{|c|c|c|c|c|c|c|}
\hline \multirow[b]{2}{*}{ Indikator Kinerja } & \multicolumn{3}{|c|}{ Kriteria Penilaian Kinerja } & \multirow{2}{*}{\multicolumn{2}{|c|}{ Hasil }} & \multirow[b]{2}{*}{ Nilai } \\
\hline & Kurang & Sedang & Baik & & & \\
\hline Load Factor (\%) & $<70$ & $70-100$ & $>100$ & 5363 & Kurano & 1 \\
\hline Kecepatan perjalanan $(\mathrm{km} / \mathrm{jam})$ & $<5$ & $5-10$ & $>10$ & 29,25 & Baik & 3 \\
\hline Headway ( Menit) & $>15$ & $10-15$ & $<10$ & 23,95 & Kurang & 1 \\
\hline Waktu Tempuh (Menit/km) & $>12$ & $6-12$ & $<6$ & 2,1 & Baik & 3 \\
\hline Waktu tunggu (menit) & $>30$ & $20-30$ & $<20$ & $10-15$ & Baik & 3 \\
\hline Waktu Pelayanan (jam) & $<13$ & $13-15$ & $>15$ & 11,01 & Kurang & 1 \\
\hline Frekuensi (Kend/jam) & $<4$ & $4-6$ & $>6$ & 2,6 & Kurang & 1 \\
\hline \multicolumn{6}{|c|}{ Nilai Rata-rata } & 1,9 \\
\hline
\end{tabular}

Penilaian dengan skala 1-3 menghasilkan kinerja rata-rata 1,9 artinya kualifikasi kinerja angkutan Trans Mebidang pada kondisi "sedang". Jika melihat hasil penilaian ini, kinerja operasional bus Damri tidak sertamerta dikatakan buruk akibat pelayanannya yang buruk. Kita perlu melihat kecenderungan akibat pengaruh pandemi covid-19 dan kebijakan pemerintah untuk bekerja, sekolah, dan beribadah di rumah. Secara umum, kinerja operasional dapat dikatakan mengalami penurunan, tetapi cenderung dapat dikatakan wajar.

\section{Pendapatan, Fare Box dan Tarif}

Pendapatan berdasarkan jumlah penumpang pada saat pandemi covid-19 sangat penting dihitung untuk mengkaji ulang tarif yang diberlakukan. Pada kondisi normal dan efektif di Tabel 8 sebelumnya diketahui bahwa jumlah normal 83.614 penumpang dan jumlah efektif 73.305 penumpang. Kemudian, pendapatan dihitung dengan mengalikan jumlah penumpang terangkut dalam satu tahun dengan tarif yang dibayarkan oleh penumpang, dan hasilnya ditunjukkan pada Gambar 3.

Gambar 3 menunjukkan 2 (dua) perlakuan tarif yakni Rp. 7.000 dan Rp. 10.000 pada kondisi normal (masa operasional 365 hari) dan kondisi efektif (masa operasional 320 hari). Kedua scenario memberikan pendapatan bersih yang berbeda. Ketika tarif Rp. 10.000 diberlakukan maka pendapatan bersih pada waktu normal adalah Rp. 282.282.621, dan pada masa efektif pendapatan bersih Rp. 179.1797.417, sedangkan dengan perlakuan tarif Rp. 7.000, pendapatan bersih masa normal adalah Rp. 31.441947 dan masa efektif aalah - 40.717.685 (rugi). Hal ini dapat diartikan bahwa pada masa pandemi covid-19, jika bus Damri Trans Mebidang rute ini beroperasi setiap hari dengan indikator kinerja standar "sedang", operasional bus masih menguntungkan. Meskipun demikian, ketika pembatasan kapasitas dan pembatasan sosial berkepanjangan, maka kondisi finansial memiliki kemungkinan yang mengkhawatirkan (Tirachini \& Cats, 2020). Di sisi lain, melihat kondisi ekonomi masyarakat yang cenderung mengarah ke berkurangnya penghasilan penumpang, maka ada kemungkinan perlunya penurunan tarif untuk meringankan masyarakat pengguna. Operator dan pemerintah menghadapi tantangan untuk tetap menjaga stabilitas perusahaan transportasi, sekaligus pula memfasilitasi mobilitas ekonomi masyarakat (Anggraeni, 2021). 


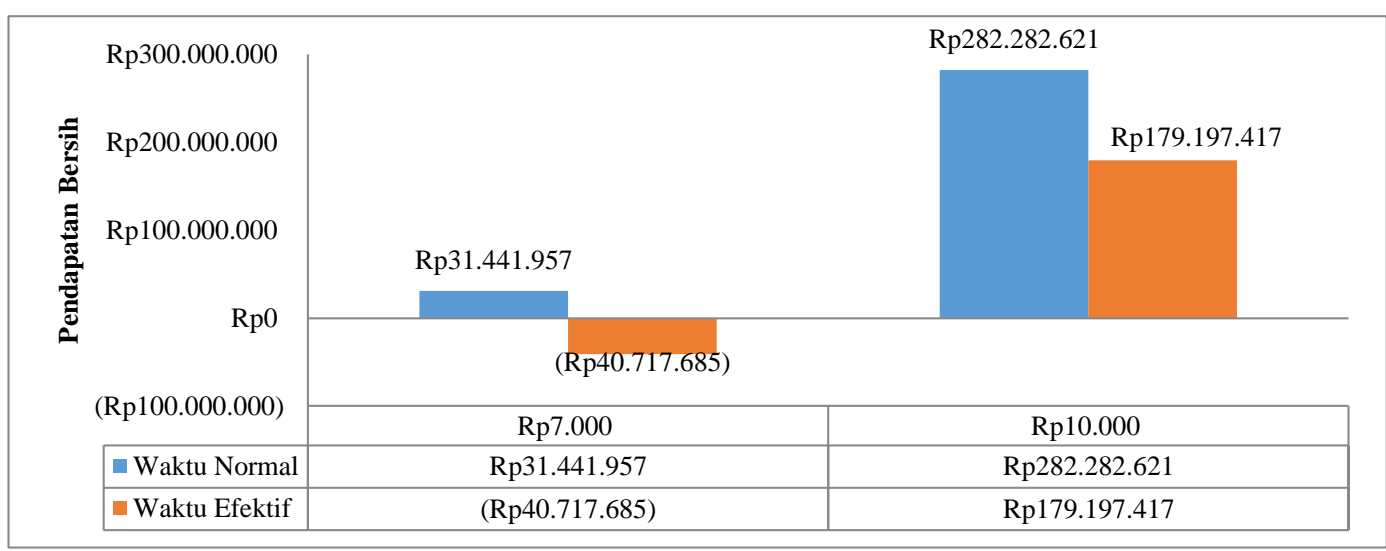

Gambar 3. Pendapatan bersih dalam satu tahun

Alasan pengambilan kebijakan dapat dilihat juga dari Fare box ratio $(f b r)$ yakni sebagai perbandingan antara pendapatan bersih dengan BOK yang terjadi. Nilai fare box ratio pada saat normal (tarif Rp. 7000 nilai $f b r=0,06$ dan tarif Rp. 10000 nilai $f b r=0,51$ ) serta pada saat efektif (tarif Rp 7000 nilai $f b r=-0,07$ dan tarif Rp. 10000 nilai $f b r=0,32$ ).

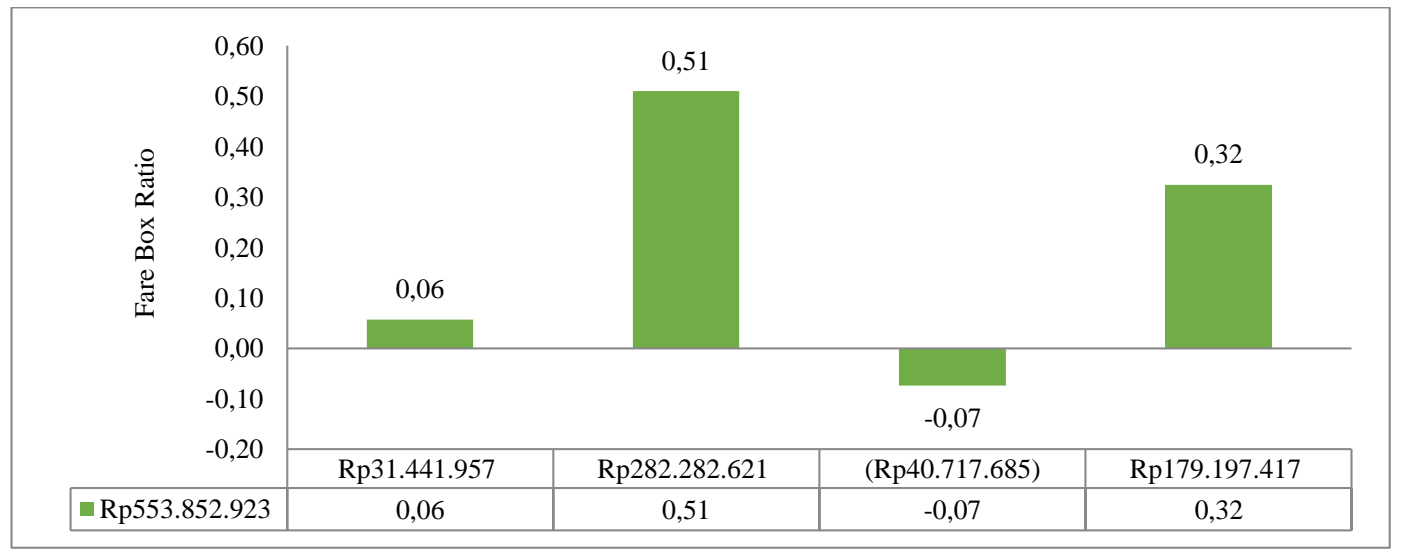

Gambar 4. Perbandingan pendapatan dengan pengeluaran (BOK)

\section{Tarif}

Berdasarkan Tabel 6 sebelumnya, hubungan antara tarif pokok dengan load factor rata-rata per bus-rit dapat dilihat lebih jelas pada gambar di bawah ini.

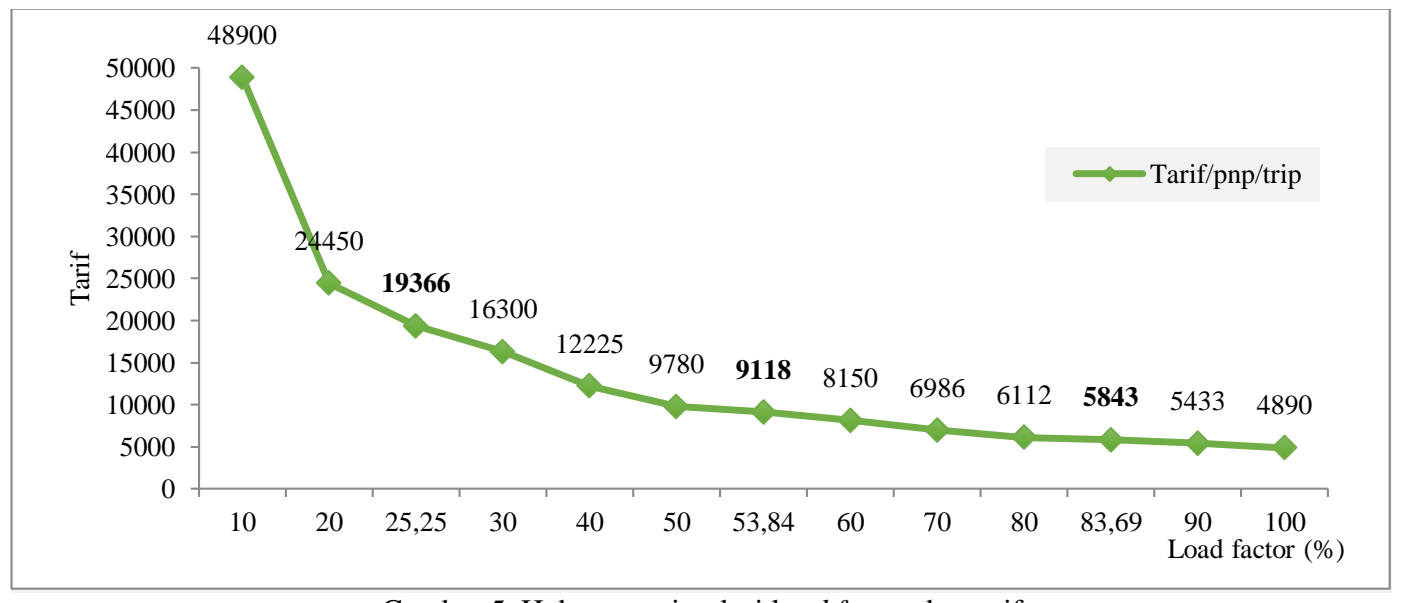

Gambar 5. Hubungan simulasi load factor dan tarif

Kurva ini dapat digunakan untuk mendukung penetapan kebijakan dalam menentukan tarif bagi pengguna jika pandemi covid-19 berkepanjangan. Pada saat load factor $70 \%$ diberlakukan nilai tarif yang diperoleh dari Grafik 1 tersebut sebesar Rp. 6.986 atau hampir sama dengan besaran tarif yang diberlakukan yang memberikan keuntungan untuk pengelola. 
Keinginan penetapan perubahan besaran tarif ditinjau dari: waktu operasional normal (365 hari), jumlah penumpang normal (83.614) dan BOK (Rp. 553.852.923) atau keuntungan nol (impas). Berdasarkan keempat asumsi tersebut maka diperoleh besaran tarif yang ditawarkan masa pandemi covid-19 adalah Rp. 6.624. Pertimbangan lain untuk menekan tarif lebih rendah dari Rp. 6.624 adalah dengan memberikan subsidi untuk pengeluaran BBM, spare part, ban dan lain-lain.

\section{Kesimpulan}

Penelitian ini dilaksanakan pada pandemi covid-19 dengan kesimpulan bahwa sebagian indikator kinerja operasional Moda Trans Mebidang dengan mengacu pada pedoman Dirjen Hubdat 2002 masih memenuhi standar. Indikator tersebut antara lain kecepatan perjalanan $29,25 \mathrm{~km} / \mathrm{jam}$, waktu perjalanan (2,1 menit/km), waktu tunggu (10-15 menit). Sedangkan, yang tidak memenuhi standar adalah load factor 56,63\%, headway 23,95 menit, waktu pelayanan 11,01 jam dan frekuensi 2,6 kendaraan/jam. Berdasarkan indikator yang diperoleh maka kinerja operasional Moda Trans Mebidang berada di skala 1-9 yang artinya kategori "sedang". Meskipun kinerja operasional yang diperoleh masih tergolong wajar akibat mulainya pembatasan sosial di bulan April, penurunan kinerja diperkirakan akan terjadi setelah bulan Juni. Hal ini berkaitan dengan surat edaran kementerian perhubungan terkait transportasi darat.

Tarif berlaku sebesar Rp. 7.000 dengan jumlah penumpang normal sebanyak 83.614 pertahun masih memberikan keuntungan Rp. 31.441.947. Untuk meringankan masyarakat di masa pandemi, kebijakan untuk menurunkan tarif masih dapat diberlakukan dengan penyesuaian menjadi Rp. 6.624 (asumsi keuntungan sama dengan nol atau impas). Meskipun demikian, perlu diingat bahwa survei penelitian dilakukan sebelum tingkat penyebaran dan skala pembatasan sosial diperbesar. Oleh karena itu, operator Trans Mebidang tetap perlu mengantisipasi penurunan pendapatan dan mempersiapkan manajemen strategis dalam menghadapi kondisi serupa di masa depan.

Penelitian sejenis dapat mengadopsi metodologi yang sama tetapi dengan pengumpulan data 7 hari berturut-turut untuk meningkatkan kualitas data. Masing-masing dapat dilakukan pada saat pembatasan skala kecil dan skala besar. Penelitian lebih lanjut dapat direkomendasikan untuk meninjau juga operasional dari sisi supir. Dengan demikian, hasil studi dapat memberikan wawasan dan informasi penting dalam mendukung perumusan kebijakan di masa bencana serupa di masa depan.

\section{Referensi}

Anggraeni, D. (2021). Dampak Pandemi COVID-19 Terhadap Sektor Moda Transportasi Darat (Bus AKAP). Jurnal Indonesia Sosial Teknologi, 2(7), 1146-1154.

Chinazzi, M., Davis, J. T., Ajelli, M., Gioannini, C., Litvinova, M., Merler, S., y Piontti, A. P., Mu, K., Rossi, L., \& Sun, K. (2020). The Effect of Travel Restrictions on the Spread of the 2019 Novel Coronavirus (COVID-19) Outbreak. Science, 368(6489), 395-400.

Google LLC. (n.d.). Google COVID-19 Community Mobility Reports. diakses 30 Juni, 2020, dari https://www.google.com/covid19/mobility

Harahap, M. G. S. (2020). Evaluasi Kinerja Angkutan Umum Bus Trans Koetaradja Koridor 1 Saat Pandemi Covid 19 [skripsi]. Universitas Syiah Kuala.

Irawan, M. Z., Belgiawan, P. F., Joewono, T. B., Bastarianto, F. F., Rizki, M., \& Ilahi, A. (2021). Exploring Activity-travel Behavior Changes During the Beginning of COVID-19 Pandemic in Indonesia. Transportation. https://doi.org/10.1007/s11116-021-10185-5

Keputusan Dirjen Perhubungan Darat No. SK.687/AJ.206/DRJD/2002 tentang Pedoman Teknis Penyelenggraan Angkutan Penumpang Umum di Wilayah Perkotaan Dalam Trayek Tetap Dan Teratur, (2002).

Keputusan Menteri Perhubungan No. 89 Tahun 2002 tentang Mekanisme Penetapan Tarif dan Formula Perhitungan Biaya Pokok Angkutan Penumpang dgn Mobil Bus Umum Antar Kota Kelas Ekonomi, (2002).

Keputusan Presiden Nomor 12 Tahun 2020 tentang Penetapan Bencana Nonalam Penyebaran Corona Virus Disease 2019 (COVID-19) Sebagai Bencana Nasional, (2020). 
Levy, P. S., \& Lemeshow, S. (2013). Sampling of populations: methods and applications. John Wiley $\&$ Sons.

Phandanouvong, S., Shah, S. M. T., Rith, M., \& Piantanakulchai, M. (2021). Travel Behavior of Commuters in Asean Countries with The Least Confirmed Covid-19 Cases During The Global Pandemic- A Case Study of Cambodia and Laos. ASEAN Engineering Journal, 11(3), 140-157.

Stini, L. O. (2020). Evaluasi Kondisi Angkutan Masal di Jabodetabek Akibat PSBB. Journal of Civil Engineering and Planning, 1(2), 104-115.

Sultan, M. A., Gaus, A., Wahab, I. H. A., \& Abdullah, A. M. (2020). Dampak Pandemi Covid-19 Terhadap Tingkat Pelayanan Moda Transportasi Speedboat Tidore-Sofifi. Jurnal Rekayasa Konstruksi Mekanika Sipil, 3(2), 89-96.

Surat Edaran Menteri Perhubungan No. 11 TAHUN 2020 Pedoman dan Petunjuk Teknis Penyelenggaraan Transportasi Darat pada Masa Adaptasi Kebiasaan Baru untuk Mencegah Penyebaran Corona Virus Disease 2019 (COVID-19), (2020).

Tirachini, A., \& Cats, O. (2020). COVID-19 and public transportation: Current assessment, prospects, and research needs. Journal of Public Transportation, 22(1), 1.

Wijaya, S. (2021). Analisis pengaruh kebijakan penanganan pandemi Covid-19 terhadap kinerja operasional BRT Transjakarta (kecepatan rata-rata, waktu tempuh, trip/day, dan headway) [Skripsi]. Universitas Tarumanagara. 


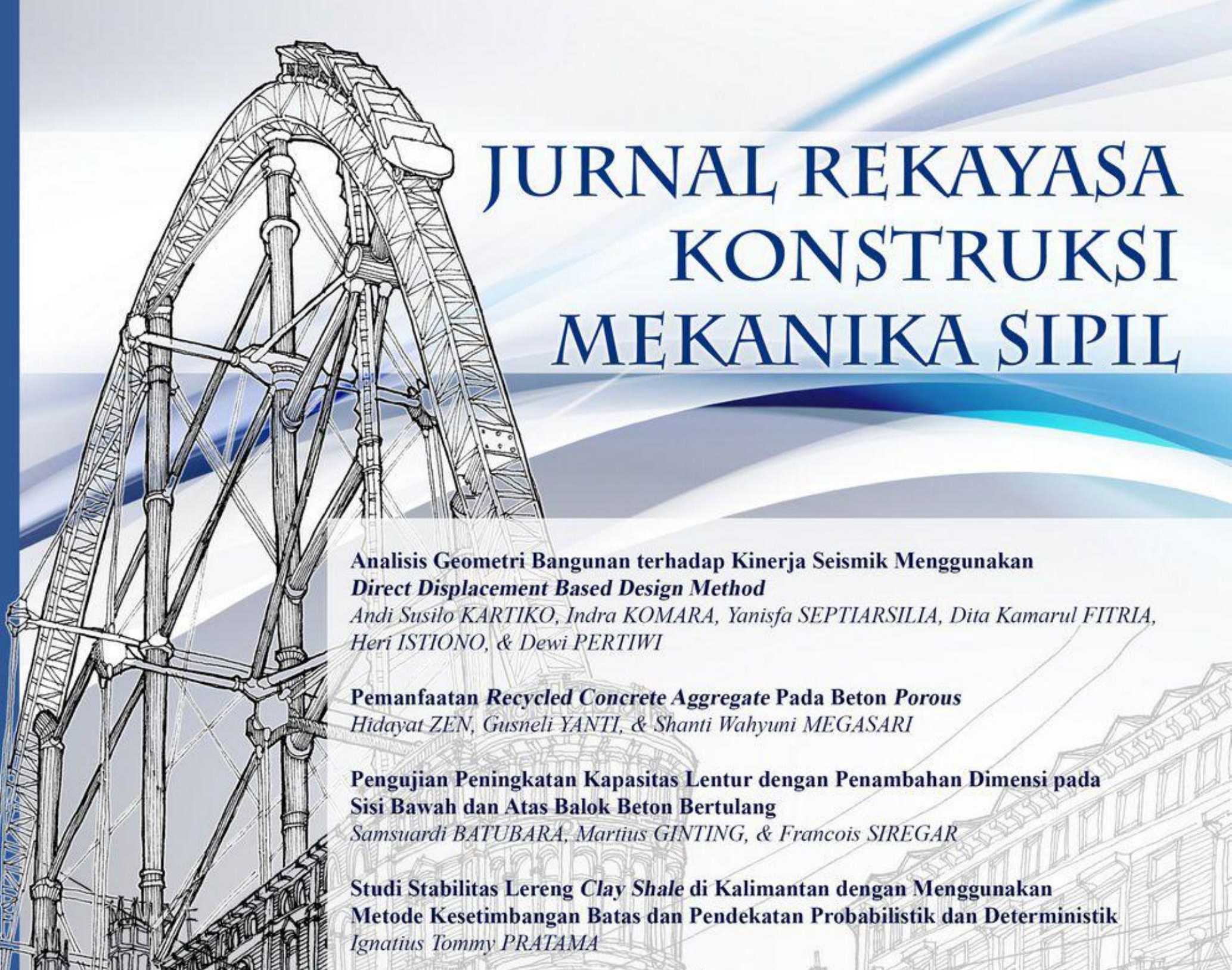

Pengaruh Tata Guna Lahan terhadap Kinerja Jalan dan Biaya Tundaan Lalu Lintas Koridor Jalan GOR Mustika Kabupaten Blora

Hartono Guntur RISTIYANTO \& Salma MFIRDAUS

Kinerja Moda Bus Trans Mebidang Trayek Lubuk Pakam-Pusat Pasar Medan di Masa Pandemi Covid-19

Oloan SITOHANG, Reynaldo SIAHAAN, \& Arnoldus Yansen Berkat LAIA

Perbandingan Produktivitas Tenaga Kerja Pembesian dan Bekisting Saat Jam Kerja Normal dan Lembur Menggunakan Metode Productivity Rating Caroline Maretha SUJANA \& Raka Aditya HAKIM

Analisis Faktor-Faktor yang Mempengaruhi Produktivitas Tenaga Kerja pada Proyek Pembangunan Jalan Tol Ruas Binjai-Langsa Seksi Binjai-Pangkalan Brandan Yolanda Ayu DAMAYANTI \& Mizanuddin SITOMPUL

Fakultas Teknik 


\section{Jurnal Rekayasa Konstruksi Mekanika Sipil (JRKMS)}

Jurnal Rekayasa Konstruksi Mekanika Sipil (JRKMS) Fakultas Teknik Universitas Katolik Santo Thomas berisi artikel-artikel ilmiah yang meliputi kajian di bidang teknik khususnya Teknik Sipil, seperti matematika teknik, mekanika teknik, analisis struktur, konstruksi baja, konstruksi beton, konstruksi kayu, konstruksi gelas, mekanika tanah, teknik pondasi, hidrologi, hidrolika, bangunan air, manajemen konstruksi, dinamika struktur, earthquake engineering, sistem dan rekayasa transportasi, ilmu ukur tanah, struktur bangunan sipil, rekayasa jalan raya, serta penelitian-penelitian lain yang terkait dengan bidang-bidang tersebut.

Terbit dalam 2 (dua) kali setahun yaitu pada bulan April dan September

\section{Penasihat :}

Prof. Dr. Drs. Sihol Situngkir, MBA. (Rektor Universitas Katolik Santo Thomas)

Ketua Penyunting (Editor in Chief) :

Ir. Oloan Sitohang, M.T. (Universitas Katolik Santo Thomas)

Manajer Penyunting (Managing Editor):

Reynaldo, S.T., M.Eng. (Universitas Katolik Santo Thomas)

\section{Anggota Penyunting (Editorial Board):}

Dr.-Ing. Sofyan S.T, M.T. (Universitas Malikussaleh)

Ir. Martius Ginting, M.T. (Universitas Katolik Santo Thomas)

Samsuardi Batubara, S.T., M.T. (Universitas Katolik Santo Thomas)

Dr. Janner Simarmata (Universitas Negri Medan)

\section{Mitra Bestari (Peer Reviewer):}

Dr.Eng. Ir. Aleksander Purba, S.T., M.T., IPM, ASEAN Eng. (Universitas Lampung, Indonesia)

Ir. Binsar Silitonga, M.T. (Universitas Katolik Santo Thomas, Indonesia)

Budi Hasiholan, S.T., M.T., Ph.D (Institut Teknologi Bandung, Indonesia)

Ir. Charles Sitindaon, M.T. (Universitas Katolik Santo Thomas, Indonesia)

Dr. Erica Elice Uy (De La Salle University, Philippines)

Dr. Ernesto Silitonga, S.T, D.E.A. (Universitas Negeri Medan, Indonesia)

Prof. Dr-Ing. Johannes Tarigan (Universitas Sumatera Utara, Indonesia)

Linda Prasetyorini (Universitas Brawijaya, Malang, Indonesia)

Dr.Eng. Mia Wimala (Universitas Katolik Parahyangan, Indonesia)

Dr.Eng. Minson Simatupang (Universitas Halu Oleo, Indonesia)

Dr. Mochamad Raditya Pradana (Keppel Marine and Deepwater Technology, Singapura)

Dr. Ir. Shirly Susanne Lumeno, S.T., M.T. (Universitas Negeri Manado, Indonesia)

Dr. Senot Sangadji (Universitas Sebelas Maret, Indonesia)

Ir. Simon Dertha, M.T. (Universitas Katolik Santo Thomas, Indonesia)

Dr. Thi Nguyên Cao (Tien Giang University, Viet Nam)

Budijanto Widjaja, S.T., M.T., Ph.D, (Guest Vol.4.No.2) (Universitas Katolik Parahyangan, Indonesia)

\section{Ilustrator Sampul:}

Yulianto, ST., M.Eng

\section{Penerbit \& Alamat Redaksi:}

Fakultas Teknik Universitas Katolik Santo Thomas

Jl. Setiabudi No. 479-F Tanjung Sari, Medan 20132

Telp. (061) 8210161 Fax : (061) 8213269

email : unika.sipil@yahoo.com 


\title{
Konten
}

\author{
REKAYASA STRUKTUR \\ Analisis Geometri Bangunan terhadap Kinerja Seismik Menggunakan \\ Direct Displacement Based Design Method \\ Andi Susilo KARTIKO, Indra KOMARA, Yanisfa SEPTIARSILIA, Dita Kamarul \\ FITRIA, Heri ISTIONO, \& Dewi PERTIWI
}

hal.

$73-84$

Pemanfaatan Recycled Concrete Aggregate Pada Beton Porous

Hidayat ZEN, Gusneli YANTI, \& Shanti Wahyuni MEGASARI

Pengujian Peningkatan Kapasitas Lentur dengan Penambahan Dimensi

pada Sisi Bawah dan Atas Balok Beton Bertulang

Samsuardi BATUBARA, Martius GINTING, \& Francois SIREGAR

\section{REKAYASA GEOTEKNIK}

Studi Stabilitas Lereng Clay Shale di Kalimantan dengan Menggunakan

Metode Kesetimbangan Batas dan Pendekatan Probabilistik dan

Deterministik

Ignatius Tommy PRATAMA

\section{REKAYASA TRANSPORTASI}

Pengaruh Tata Guna Lahan terhadap Kinerja Jalan dan Biaya Tundaan

Lalu Lintas Koridor Jalan GOR Mustika Kabupaten Blora

Hartono Guntur RISTIYANTO \& Salma M FIRDAUS

Kinerja Moda Bus Trans Mebidang Trayek Lubuk Pakam-Pusat Pasar

Medan di Masa Pandemi Covid-19

Oloan SITOHANG, Reynaldo SIAHAAN, \& Arnoldus Yansen Berkat LAIA

\section{MANAJEMEN KONSTRUKSI}

Perbandingan Produktivitas Tenaga Kerja Pembesian dan Bekisting Saat Jam Kerja Normal dan Lembur Menggunakan Metode Productivity Rating Caroline Maretha SUJANA \& Raka Aditya HAKIM

Analisis Faktor-Faktor yang Mempengaruhi Produktivitas Tenaga Kerja pada Proyek Pembangunan Jalan Tol Ruas Binjai-Langsa Seksi BinjaiPangkalan Brandan

Yolanda Ayu DAMAYANTI \& Mizanuddin SITOMPUL 


\section{Pengantar Redaksi}

Puji dan syukur kami sampaikan kepada Tuhan Yang Maha Esa karena atas kasih karuniaNYA kami dapat menyelesaikan penerbitan Jurnal Rekayasa Konstruksi Mekanika Sipil (JRKMS) Volume 4 Nomor 2, di bulan September tahun 2021 ini. Jurnal ini fokus pada beragam subbidang dalam Teknik Sipil antara lain Rekayasa Struktur, Rekayasa Geoteknik, Rekayasa Transportasi, Teknik Sumber Daya Air, dan Manajemen Konstruksi. Namun, tidak menutup kesempatan bagi subbidang lainnya yang berkaitan dengan keilmuan Teknik Sipil.

Satu hal yang patut disyukuri pula adalah semakin terkendalinya kondisi pandemi COVID-19 di Indonesia. Hal ini turut menjadi angin segar pendorong bagi kita untuk meningkatkan semangat meneliti dan berkontribusi pada bidang keilmuan kita. Pada edisi ini, kami menerima banyak artikel dengan topik yang menarik. Ada 8 peer-reviewed artikel yang terbit di Volume 4 Nomor 2 ini, yang mana terdiri atas 3 (tiga) artikel dalam topik Rekayasa Struktur, 1 (satu) artikel dalam topik Rekayasa Geoteknik, 2 (dua) artikel dalam topik Rekayasa Transportasi, 2 (dua) artikel dalam topik Manajemen Konstruksi.

Seiring dengan semakin tingginya tuntutan kualitas publikasi ilmiah oleh pemerintah, pada edisi ini tim editorial berusaha meningkatkan kualitas review dan penyuntingan dengan harapan semakin baik pula kapasitas kita bersama, dan kualitas artikel ilmiah yang kita terbitkan. Dewan redaksi menyampaikan apresiasi tinggi kepada para penulis yang tulisannya diterbitkan pada volume ini, atas kerja samanya merespon komentar dan rekomendasi dari tim editorial dan mitra bestari. Kami menyadari bahwa butuh dedikasi dan investasi waktu untuk menghasilkan karya tulis yang baik dan bermanfaat. Terkhusus, kami bersyukur atas para mitra bestari yang tidak pernah lelah dalam menyambut permintaan kami dengan penuh dedikasi.

Sebagai penutup, harapan kami adalah semoga jurnal ini dapat menjadi media ilmiah yang bermanfaat dan informatif bagi rekan-rekan dan praktisi bidang ketekniksipilan di Indonesia. Salam hangat dan Salam sehat.

Medan, September 2021

Tim Editorial 
